\title{
Local Governance Institutions, CBNRM, and Benefit-sharing Systems in Namibian Conservancies
}

\author{
Alfons Wabahe Mosimane $e^{1} \&$ Julie A Silva ${ }^{2}$ \\ ${ }^{1}$ Multidisciplinary Research Centre, University of Namibia, Namibia \\ ${ }^{2}$ Department of Geographical Sciences, University of Maryland, United States \\ Correspondence: Alfons Wabahe Mosimane, Multidisciplinary Research Centre, University of Namibia, Namibia. \\ E-mail: amosimane@unam.na
}

Received: December 16, 2014 Accepted: January 28, 2015 Online Published: March 30, 2015

doi:10.5539/jsd.v8n2p99

URL: http://dx.doi.org/10.5539/jsd.v8n2p99

\begin{abstract}
The provision of socio-economic benefits to community members is a key component in the design and implementation of community based natural resources management (CBNRM) initiatives in rural areas. Namibian CBNRM legislation requires that the local governance systems develop a benefit sharing plan (MET, 1995). Local governance systems that are developed within CBNRM programs determine the types and amounts of benefits that community members receive. This paper investigates the role of local governance in establishing benefit-sharing mechanisms and whether local governance facilitates or impedes the equitable distribution of benefits. We also examine whether community characteristics often highlighted in community based conservation literature as facilitating decision making in CBNRM (i.e., size of community, level of community homogeneity, and existence of shared norms) contribute to better local governance for benefit sharing. We use two case studies in Namibia to examine local governance and benefit sharing (Uibasen conservancy in Kunene region and Mayuni conservancy in Caprivi region). We draw on qualitative data from in-depth interviews with conservancy residents conducted in 2011. The findings of the study suggest local governance institutions in conservancies have not developed adequate benefit-sharing systems, and the expectations of conservancy members are largely based on speculation about what they should receive stemming from unclear guidelines regarding realistically deliverable benefits. We find that community characteristics have little impact on local governance outcomes with regards to benefit-sharing systems. This suggests that local governance structures need more external support and oversight in designing and implementing methods for distributing benefits to community members. We argue that fairness and equitable sharing of benefits can only be achieved when it is an explicit objective of the benefit-sharing systems used by local governance structures and involves transparency.
\end{abstract}

Keywords: benefit sharing, CBNRM, conservation, local governance institutions, Namibia

\section{Introduction}

Architects of community based natural resource management (CBNRM) initiatives emphasize the importance of incentives in ensuring successful conservation outcomes, arguing that community members will better manage natural resources if they derive benefits from doing so (Child, 2004; Hulme \& Murphree, 2001; Long, 2004; Mbaiwa, 2004; Murphree, 1993, 1995). These benefits are intended to help people develop positive attitudes and behaviors towards wildlife and conservation (Hulme \& Murphree, 2001; Scanlon \& Kull, 2009). Theoretically CBNRM offers two types of advantages to communities that participate: economic benefits, such as employment or dividends from tourism profits, and non-economic benefits, such as community capacity building and strengthening of social networks (Ashley \& LaFranchi, 1997). Proponents of CBNRM argue that benefits must outweigh the costs of conservation, particularly losses from human-wildlife conflict (Hulme \& Murphree, 2001; Jones, 1999b, 1999c; Murphree, 1993; Thakadu, 2005). However, (Nkhata, Breen, \& Mosimane, 2012) find that the relationship between expected benefits and conservation behavior is complex. For example, perceptions that benefits are being unfairly distributed may cause people to opt out of CBNRM programs even when economic gains occur (Silva \& Mosimane, 2013). Thus, benefit distribution mechanisms and the factors associated with their success merit more attention when examining CBNRM programs.

This paper examines the relationship between local governance institutions, communities, and benefit-sharing systems in Namibian CBNRM programs. Namibian conservancies are community based local governance 
institutions that give communal land residents rights to manage wildlife and tourism in order to derive economic benefits and diversify their livelihood opportunities (Jones, 1999b; Scanlon \& Kull, 2009). The Namibian conservancy program began in 1996 and has been widely viewed by practitioners as a successful model for integrated conservation and development programs (ICDPs) (Child, 2004; Hoole, 2009a, 2009b; Suich \& Child, 2009). The study examines how local governance institutions manage the distribution of benefits and how this is influenced by community characteristics and social structures. Drawing on a case study of two Namibian conservancies, this paper first examines the extent to which benefit-sharing systems exists in practice and how successfully they lead to equitable distribution of benefits. Secondly, we investigate how benefit sharing is influenced by the community characteristics (Agrawal \& Gibson, 1999) that are often associated with more equitable outcomes in CBNRM programs (i.e., small spatial extent, homogenous communities, and shared community norms). Collective action scholars suggest that the size of spatial unit, homogeneity of the community and the common interests and shared norms are important in successful implementation of common pool resources management (Agrawal, 2001; Agrawal \& Gibson, 1999; Jones \& Murphree, 2004; Ostrom, 1990; Poteete \& Ostrom, 2004)

\section{Literature Review}

Literature on common pool resources management has shown that local governance institutions have long histories of facilitating equitable allocation of benefits to resource users (Agrawal, 2001; Nkhata \& Breen, 2010; Ostrom, 1990). CBNRM often involves the devolution of national resource management to the local level and relies on local institutions to facilitate transparency, accountability and participation (Balint \& Mashinya, 2008a, 2008b). However, literature suggests that benefits from CBNRM rarely reach community members in an equitable manner. Dressler and Büscher (2008) observe that CBNRM benefits the private sector more than it does rural populations. Igoe and Croucher (2007) note that benefits rarely flow to community members involved in CBNRM projects and, if they do, these benefits only reach a few well-placed community members. Silva and Mosimane (2013) find that Namibian conservancies do provide economic benefits to some members, but fail to deliver community-wide improvements (e.g., improved infrastructure and services), and thus improve the livelihoods of a relatively small proportion of members. The type of benefits (i.e., monetary or non-monetary) and how they are distributed is important because it influences the perception of whether benefits are meaningful, appropriate, sufficient and equitable (Scanlon \& Kull, 2009; J.A. Silva \& Mosimane, 2012). This suggests that benefit sharing must involve negotiations of dynamic, different and competing interests within the community and local governance institutions (Nkhata, Breen, et al., 2012).

Relatively few studies in natural resources management literature, explore the relationship between local governance institutions and benefit-sharing systems. Nkhata, Breen et al. (2012) expose the gaps in benefit sharing policy research and stress the importance of understanding different forms of benefit sharing arrangements in communities. Literature suggests typologies for understanding benefit sharing within the governance of social ecological systems (Nkhata, Mosimane, Downsborough, Breen, \& Roux, 2012). The typologies consist of three categories of benefit sharing arrangements such as collaborative, market oriented and egalitarian. Collaborative benefit-sharing systems are those designed to regulate the relationship between the state and local communities in the allocation of benefits. Market oriented benefit-sharing arrangements refers to an approach that involves voluntary exchanges in reciprocal relationships where one party offers a favor in return for something else. Egalitarian denotes benefit-sharing arrangements based on the principle that all people are equal and deserve equal rights and opportunities. Nkhata, Breen et al. (2012) and Nkhata, Mosimane et al (2012) note the need for further empirical research regarding how different types of benefit sharing in natural resources management arise.

The conventional argument in common pool resource management (Balint \& Mashinya, 2008b; Murphree, 1993; Ostrom, 1990) is that small spatial units are more appropriate for the management of CBNRM because it devolves management to those close to the resource, facilitates decision making, transparency and accountability (Jones, 1999b) and reduces the transaction costs to the community of managing natural resources (Agrawal \& Gibson, 1999). Jones (1999a) observes that larger spatial units restrict the flow of information, accountability between the community and conservancy committee and reduce community cohesion. Murphree (2009), using the Masoka case in Zimbabwe, demonstrates that a relatively small population facilitates better benefit sharing in that the demands of the type and amount of benefits is modest. Similarly, Balint and Mashinya (2008) in their study of Mahenye in Zimbabwe confirmed that small populations facilitate community participation in conservation projects. Scanlon and Kull (2009) in their study of Torra conservancy in Namibia assert that a smaller population makes the distribution of benefits easier within the conservancy because fewer people are involved and thus each individual receive more benefit. They further suggest that the distributions of benefits 
within smaller conservancies are more responsive to the expectations of members.

Agrawal and Gibson (1999) argue that it is generally assumed that communities in rural area are homogenous because of their location, sharing the same resources and language. This notion is also commonly inferred about rural communities in southern Africa (Child, 2004; Fabricius, Koch, Magome, \& Turner, 2004; Suich \& Child, 2009). Jones (1999a) observes that in the formation of various conservancies a number of conflicts between interests groups has always been evident, resulting in the delayed registration of some conservancies. Ethnic conflicts have also been documented in some conservancies (Jones, 1999b; Nott \& Jacobsohn, 2004). This raises the question, whether the degree of homogeneity of the conservancy members influences the distribution of benefits to members in conservancies? Through day-to-day interaction community members develop common interests and norms that characterize the community (Agrawal \& Gibson, 1999). Literature suggests that common interests and shared norms have the potential to contribute to better cooperation within the community to make decisions on the use and management of natural resources (Child, 2004; Fabricius et al., 2004; Suich \& Child, 2009). Where shared norms are based on the use and management of natural resources it could facilitate behaviors that promote the conservation of natural resources.

\section{Study Sites and Research Design}

\subsection{Study Sites}

The study examines two conservancies in Namibia: Uibasen conservancy in Kunene region and Mayuni conservancy in Caprivi region. Both these conservancies were among the first established in Namibia and therefore have relatively long histories. Governance structures in both conservancies are similar according to their respective constitutions. In both conservancies a management committee oversees the day-to-day operation of the conservancy and manages the incoming financial revenue on behalf of the members. Thus, the conservancy management committee functions as the main local governance institution for the conservancy. Election of conservancy management committee members takes place every three years, and, in theory, positions are open to all conservancy members. Both conservancies have employed office personnel as well as community game guards for monitoring wildlife and attending to human wildlife conflicts. Both conservancies have also established joint venture agreements with lodges and have community owned campsites. Conservancy governance structures differ driven by community characteristics and local social systems.

Mayuni conservancy is located in the tropical northeastern part of Namibia. This conservancy was registered in 1999 (NACSO, 2006). Due to the high rainfall in the region, livelihoods are predominantly supported by subsistence crop farming. Tourism in the region is based on rich biodiversity and river systems that support an abundance of wildlife, in particular elephant, buffalo and hippopotamus (Mendelsohn 2002). Most tourism facilities are developed on the banks of river systems, and similarly conservancies are mainly established around these systems. The Caprivi region has the second highest number of conservancies after the Kunene. The population within the conservancy is estimated around 2,400, the high density in part due to water availability for both household and livestock. People generally cultivate crops in the land near riverbeds where rich, alluvial soils are conducive to higher yields. In addition, many families maintain secondary fields in forest areas as a precaution against crop raiding by wildlife that tend to target fields near the river (Mosimane, 1999).

The community of Mayuni is made up of several ethnic groups, such as the Mbukushu, Mafwe and a small number of Kxoe (San). The community falls under the Mashi Traditional Authority. The traditional authority structure in Mayuni has a long history and their responsibilities include community leadership, local judicial matters, land allocation and management, and guiding the conservancy with its wildlife management (Humphrey \& Humphrey, 2003). Although these groups have their respective languages, the most commonly spoken languages are Silozi and Sifwe. The conservancy is located close to a main road to the town of Katima Mulilo. 


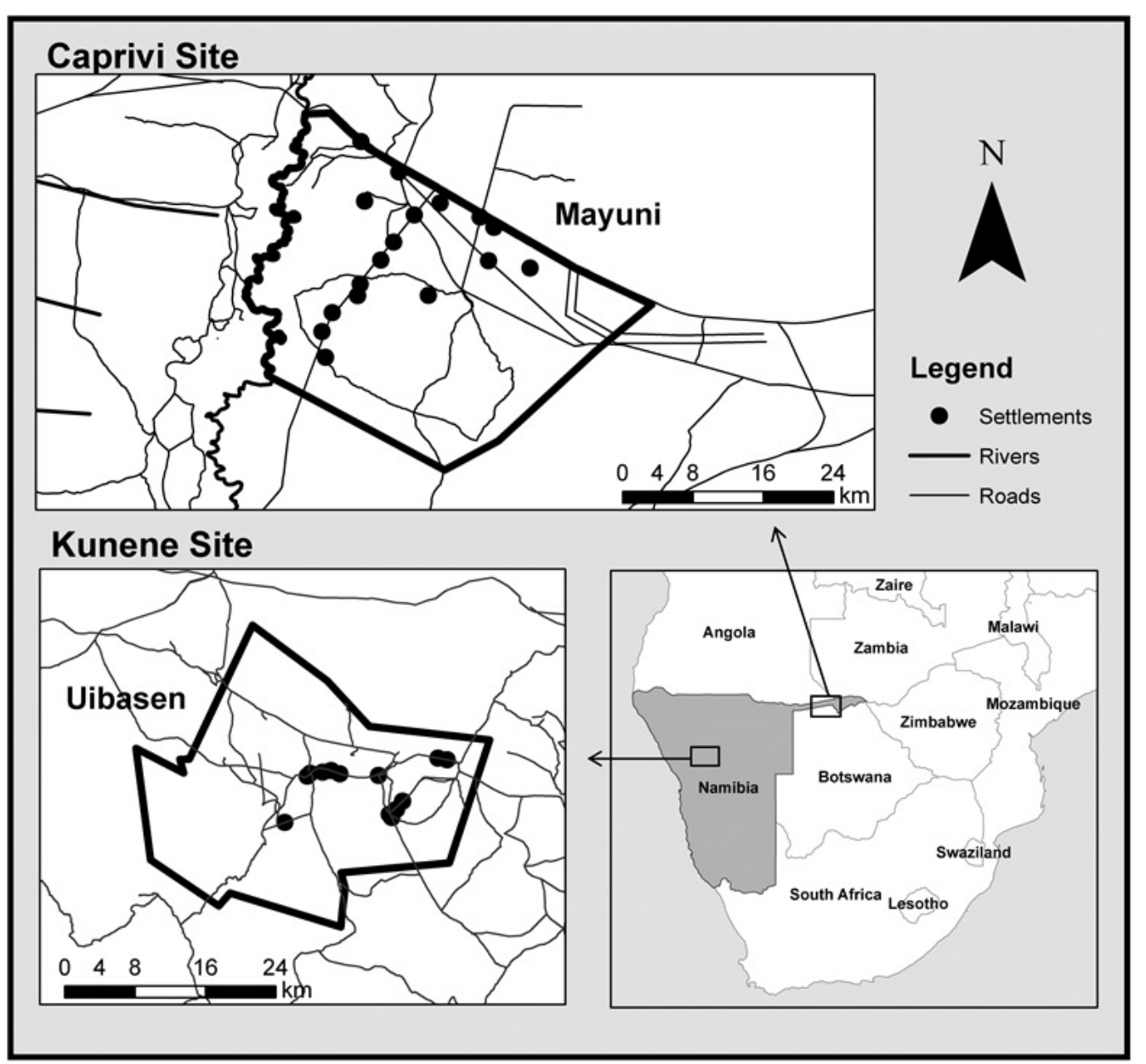

Figure 1. Map showing Mayuni and Uibasen conservancies in Namibia

The Uibasen conservancy is located in the northwest, arid to semi-arid coastal area of Namibia. The conservancy was also established in December 1999 (NACSO, 2006). Due to the aridity of the area, the conservancy is sparsely populated and the main livelihood is subsistence livestock farming (Uiseb \& Mosimane, 2004). The region is known for its scenic landscape and wildlife abundance making it a major tourism attraction in Namibia (Jones, 1999b). The presence of a world heritage site and other natural attractions such as the dolomite pipes and burnt mountain establishes the conservancy as the tourism hub of the region (Uiseb \& Mosimane, 2004). The conservancy has two lodges and two campsites that provide employment to community members. These employment opportunities attract people from surrounding areas to settle in the conservancy. More recent migrants that settled in the conservancy for employment now outnumber conservancy members, and this has resulted in the conservancy developing specific provisions in their constitution to manage the influx of people.

Area residents are mainly members of the Damara/Nama ethnic group and speak Khoekhoegowab. The majority also share a common religion (Lutheranism). This area of Namibia experienced considerable interference from the former colonial governments of Germany and, later, South Africa (Adams, Werner, \& Vale, 1990). In particular, colonial governments displaced many of the Nama/Damara from their traditional lands and dismantled traditional authority structures. Although people re-settled in the area after the Odendaal Commission of 1964 support for traditional authorities remains weak relative to other parts of the country (Uiseb \& Mosimane, 2004). Despite their relatively close proximity to the country's main economic centers (e.g., Windhoek), people remain largely isolated.

\subsection{Research Design}

This study draws on 85 in-depth interviews conducted in Uibasen and Mayuni conservancies in 2011. These interviews were a follow-up study with participants of a socio-economic survey conducted with community 
members in both conservancies in 2009. Empirical research often excludes more geographically isolated households, despite the fact that these tend to be poorer and most in need of poverty interventions (Chambers, 1983). In order to construct geographically representative samples to better capture the characteristics and perspectives of the entire community under observation, we first mapped all households in each study area. In Uibasen conservancy we conducted a census of 67 households due to the small population size. In Mayuni, we used a stratification procedure, mapping households according to geographic location, and then randomly sampling $40 \%$ of households in our study area $(n=175)$ for interviews from these maps.

After analysis of the 2009 survey data we identified several themes for follow-up interviews, including perceived conservancy benefits, decision-making criteria for membership, and challenges associated with living in conservancies. These themes became the focus of the qualitative study that was conducted in 2011. This allowed us to build themes from the larger sample before investigating them more fully with longer, more in-depth follow-up interviews. The interviews were conducted with randomly selected participants from the 2009 surveys, leading members of the traditional authorities, conservancy chairpersons, NGO officials in the areas, and some government officials. Of those interviews, 42 and 43 were conducted with residents of Mayuni and Uibasen, respectively. Students and researchers from the University of Namibia (UNAM) administered interviews with respondents in both conservancies. All interviews were conducted in local languages, after we explained to respondents the purpose of the study, pledged confidentiality, and received their consent to participate in the study. The interviews were audiotaped with permission, translated into English by UNAM staff, and entered into an NVIVO data base to facilitate content analysis. We also draw on field observation during the four years of data collection to inform the interpretation of the data.

\section{Results}

\subsection{Benefit-sharing Systems and Perceptions in Conservancies}

The Namibia CBNRM policy requires conservancies to develop and agree on a distribution plan that articulates how benefits will be distributed among conservancy members (MET, 1995). The policy further specifies that conservancy constitutions shall outline the procedure that the conservancy management committee will follow in ensuring the distribution of benefits. The regulations clearly specify that benefit sharing must be equitable and fair, but they do not provide guidelines for how to accomplish this goal. It was only in 2008 that the MET provided a basic structure for a benefit distribution plan, which states the plan must indicate the overall objective of benefit distribution and the specific target groups for benefits. The plan must also indicate the means by which benefits will be distributed. However our research indicates that, as of 2011, most interview respondents reported that no benefit distribution plans have been developed in Uibasen or Mayuni, although a range of ad hoc approaches and priorities have been used to distribute benefits. Jones (1999b: 11) observed, 'The conservancy policy is flexible in its approach to how communities should use their income, leaving it to the community to decide whether wildlife and tourism income should be used for community projects or as dividends to individual households.' Namibia's conservancy policy requires the process to be consultative and participatory to incorporate the views of conservancy members. The draft plan would then be presented at various community platforms for conservancy members input before it is final presented at the Annual General Meeting (AGM) for approval, followed by implementation.

In both Uibasen and Mayuni conservancies, the constitutions state the need for developing benefits distribution plans as prescribed in the legislation. The constitutions also state the principles that should guide such benefit sharing initiatives within the respective conservancies. However, evidence from the qualitative interviews and other literature suggests that equitable benefit-sharing systems have not been developed. One respondent in Uibasen, an employee of the conservancy, said, 'The conservancy has a distribution plan. The benefits that members get include diesel pumps, vaccinations of livestock, cash benefits, tuition grants for university students, a scheme that pays school fees and groceries to children especially orphans and elders.' However, the majority of respondents indicated that some members of the conservancy benefited much more than others. In particular, respondents commonly pointed out that several people serving on the conservancy management committee (and some of their family members) now had cars, nice houses, and owned the only small shops in the area.

In general, we find the perceived benefits accruing to community members belonging to the conservancy fall short of the expected benefits, which has resulted in increasing dissatisfaction and despondency towards the conservancy in both case study areas. This is the case regardless of their spatial extent, the degree of community heterogeneity, and degree of shared social norms. Interview data review very low levels of trust in conservancy management communities in both Uibasen and Mayuni. Respondents in both sites commonly complained that the conservancy management committees failed to inform residents of financial decisions, and a widespread 
belief exists that these elected representative mismanage funds generated by tourism revenue. One Mayuni respondent said, 'They [the conservancy management committee] lied to us about what we were going to get.' In the words of another member of the Mayuni conservancy, 'I told you that I don't know anything about the conservancy because I eat [get] nothing from it. That is what has discouraged me.' The majority of Mayuni respondents said they received no benefits from the conservancy. In the words of one respondent, 'there is not enough money coming from the conservancy so we do not benefit. We always find out at the end of that year when [the conservancy management committee] gives a report at the annual meeting that a lot of money is missing. Conservancy workers are not even paid which is why I say that the conservancy is not reliable.' And another said, 'They [members of the conservancy management committee] are not helping us. We are getting nothing. We are just losing money because wild animals eat from our fields.' These statements suggest that lack of benefits causes community members to feel disconnected from the conservancy and thus creates a distance between conservancy members and the local governance institution.

Although both conservancies derive revenue from the management of natural resources, in Mayuni most of revenue is absorbed by institutional management and administrative overhead costs and nothing or very little is left for benefits to communities (NACSO, 2008). These costs are rarely well defined for community members so they do not understand their importance in maintaining the conservancy. This lack of understanding coupled with their limited participation in decision making about the allocation of funds has elicited several complaints. In the words of one respondent, 'everything with this conservancy is not good. It cannot be trusted as our conservancy. It's of no use to us. They are just eating [stealing] the money.' The statement suggests community members believe the conservancy generates more money than the conservancy management claims to receive which is a key point of tension between the governing body and the residents. In Uibasen, higher tourism revenue translates into more benefits for members, but respondents still describe the distribution process as lacking transparency because they are depended on the whims of local elites.

Conservancies have been willing to codify and revise other aspects of constitutions, such as the role of traditional authority in Uibasen, and mechanisms for including community input into wildlife management plans. In general, conservancy constitutions have gone from very vague to more detailed over the life span of both Uibasen and Mayuni conservancies. But detailed plans for benefit sharing are still missing. This suggests the lack of capacity to develop or facilitate a consultative process of developing benefit-sharing plans. The government and NGOs need to assist conservancies in addressing this gap in order to facilitate the equitable distribution of benefits. The recently developed training manual by the Namibia CBNRM Support Organization (NACSO), Institutional Development Working Group, recognizes the need to provide conservancies with support in developing benefit distribution plans. The manual is specifically developed for the training of conservancy staff, conservancy managers and the respective conservancy management committees (NACSO, 2012).

\subsection{Community Characteristics and Benefit Sharing}

In order to better understand why equitable benefit-sharing systems have failed to materialize in Uibasen and Mayuni, we examine how community characteristics influence the emergence of such schemes. In the following section, we assess how the size of spatial unit, homogeneity of the community and the common interests and shared norms facilitate or impede benefit sharing in both case studies.

\subsubsection{Does Community as a Small Spatial Unit Facilitate Better Benefit Sharing?}

Uibasen and Mayuni conservancies both cover relatively small land areas and this should theoretically, encourage regular interaction and participation between conservancy members and the conservancy management committee. However, in Uibasen member households tend to be isolated and limited transportation options reduce their ability to interact in decision-making processes regarding the conservancy. In Mayuni, members live closer together, which better facilitates community-level interactions, but more members also means more individuals are involved in establishing consensus on how to manage the conservancy. In both conservancies communities we find evidence that members feel they are not adequately consulted regarding management decisions.

One conservancy member in Caprivi summed up the general sentiment of respondents regarding their limited ability to participate in management decisions, saying 'I don't know how the conservancy works since they are not explaining anything to us. Like yesterday we had a meeting with the people from the conservancy and most of the old people walked out since they did not understand anything the committee was saying.' Furthermore, respondents report being turned away when they ask for information about the management of the conservancy. In the words of one Mayuni member, 'Sometimes when we meet them (conservancy management committee 
members) we ask about ... [the conservancy] and they say 'why are you constantly asking us...?' Conservancy members in Kunene express similar dissatisfaction. One respondent reports 'the conservancy committee asks what the community needs and we inform them what we need to develop ourselves. We never receive what is promised by the conservancy.' The statement provides evidence of a lack of trust in the management, coming from the earlier disconnect between residents and management regarding the revenue the conservancy receives.

Our findings, like those of Scanlon and Kull (2009), suggest that the population density of an area have much larger effects than spatial extent in determining the degree of benefits received by the population. Where the population size is large, such as in the Mayuni conservancy, distributing benefits to households makes the benefits received insignificant, as people only receive a few dollars per annum. This suggests that a benefit sharing mechanism that promotes community wide benefits (e.g., investments in education and health infrastructure) might be more appropriate in densely populated environments (J.A. Silva \& Mosimane, 2012). Community wide benefits would include infrastructure improvements or community development projects that could enhance the wellbeing of all conservancy residents. One respondent said, 'I benefit nothing [from the conservancy]. There have been no developments or changes here. The only ones who benefit are those who are employed in parks and by the conservancy.' Another said, 'I can say that there are no developments in this area which were brought about after the establishment of conservancies, nothing at all.' These quotes suggest that if community-wide benefits existed, people would see more concrete evidence that the conservancy has improved overall wellbeing. Community perceptions of benefits in Mayuni suggest community-wide benefits are more appropriate in densely populated areas.

In contrast, a smaller population like in Uibasen derives direct economic benefits that are significant. One respondent said, "the conservancy provides cash (up to $\mathrm{N} \$ 5,000$ ) and two goats to each member of the conservancy each year. Some people use the money to buy goats. We bought a donkey and paid off some bills.' Due to small population there is a higher likelihood that every members of the community receives benefits as the respondents confirm in the above quote. However, both members and non-members living in the conservancy reported strong preferences for community wide benefits since these would accrue to all area residents. A respondent said, 'I just wish that the people could get better houses, toilets and water and that the rubbish in the area can be removed with trucks. That would change people's lives. But then I am not fully in the conservancy management committee so I don't have the strength to make them do this.' Another said, 'There is really nothing that was built by the conservancy, apart from the office. We are still waiting for the kindergarten and the clinic. The conservancy said they would build these things but nothing has happened. Khorixas is 100 $\mathrm{km}$ far from here and we need those things. There are lodges and campsites even more then the past but there are no community projects in the area.' Although, direct economic benefits might be preferred in the benefit sharing mechanism developed for CBNRM, community members still suggests a combination of both direct and community wide benefits would have a greater impact on improving their livelihood. The benefits community members suggests to be incorporated in the benefit-sharing systems also have the potential to support a clean environment which is an essential component for nature based tourism, such as sanitation systems in their areas.

We find small spatial units do not necessarily lead to more equitable benefit sharing or facilitate better local governance regarding benefits distribution. The local governance structures appear constrained not by distance, but by the number of members that are eligible for benefits and the amount of revenue generated. In the absence of high conservancy revenues, members are likely to feel that they do not receive a fair share. The difficulties associated with developing equitable benefit sharing in high-density areas may reduce incentives for local governments to implement these measures.

\subsubsection{Does Community as a Homogenous Social Structure Facilitate Better Benefit Sharing?}

Uibasen conservancy is fairly homogenous in terms of ethnicity and language, but a large proportion of the population is not eligible for membership since they migrated to the area for work. This contributes to high levels of social conflict around the issue of member benefits. For example one respondent notes, "The opportunities are not fairly distributed, the area belongs to the conservancy and if every household would benefit ... then it would be fair. But only some people benefit, mostly the members benefit, I feel everyone should be treated fairly, if there are good things, it should be distributed equally to everyone.' Findings also suggest that local elites have appropriated a high share of the benefits, undermining member satisfaction. 'Sometimes the conservancy gets income but we in the community don't see the money.' Another respondent noted, 'the conservancy chairperson and his close family are the only ones who benefit and get jobs.'

Mayuni conservancy is considerably more heterogeneous in terms of ethnicity and languages spoken but demonstrates evidence of greater social cohesion mainly due to a widely shared respect for their traditional 
authorities (Julie A Silva \& Mosimane, 2014). As a result, there has been less social conflict regarding benefits, despite the fact that respondents described both economic and non-monetary benefits as insignificant for the majority of community members. In the words of one Mayuni member, 'I will say that the conservancy brings development even though some of us cannot see it. There is no benefit on my side.' Although Mayuni members were more heterogeneous they had fewer complaints that benefits were distributed unfairly. Rather, they were more concerned with the lack of compensation for human wildlife conflict related losses (i.e., crop raiding by elephants and livestock deaths due to lions and other predators) which plays a big role in causing dissatisfaction with conservancies.

In our study, we find ethnic homogeneity plays a very small role in facilitating equitable benefit sharing, even when economic gains do accrue to conservancy members. Uibasen can arguably be seen as more ethnically homogenous than Mayuni, but complaints about unfair distribution of benefits are more widespread. These inequalities are mostly explained as a result of length of residence (e.g., longer term residents benefit more than more recent migrants) or social class (e.g., the local elite have been able to benefit more than others). But there is no clear relationship between ethnicity and residency or social class in either conservancy.

\subsubsection{Do Common Interests and Shared Norms Within a Community Facilitate Better Benefit Sharing?}

In Mayuni conservancy, we find communities are made up of individuals that have lived together in the same area for generations and have developed shared norms and culture. The norms and culture facilitates social cohesion amongst community members and is reinforced by established traditional authority structures (Julie A Silva \& Mosimane, 2014). We find that shared norms and culture give community members a common interest in terms of livelihood and shared use of natural resources. Communities established conservancies because of a common interests to conserve wildlife for future generations and the potential benefits they could receive to improve their livelihoods (Jacobsohn \& Owen-Smith, 2003; Jones, 1999b, 1999c; Long, 2004). Establishing a conservancy was in a way reinforcing the common interest that bonds members to a particular common purpose.

Uibasen residents, in contrast, belong to one of two distinct groups, native residents who are members of the conservancy and more recent migrants who are non-members. The findings in Uibasen conservancy shows community members had fewer common interests and shared norms because the distinct groups of members versus non-members, with one group receiving benefits while the other did not.Most residents, both members and non-members, complain about benefits being unfairly distributed. One notable exception is the few farming families that do not work in the tourism industry. For example, one farmer said, 'Now that tourism is established, we have lodges and a filling station and campsite. The Conservancy gets income from the lodges. The Conservancy bought us livestock and we also bought some with the money we received from the conservancy.' Non-members, however, do not receive these types of benefits. While some members express sympathy with those who cannot join, and thus cannot receive benefits, the majority of respondents in Uibasen expressed the opinion that more recent migrants should not be allowed to join.

In the words of one respondent, 'Non- members who came for work in the area want to be registered and they are not allowed. If they don't have jobs they should go back to their own areas, but they refuse and build houses instead. They don't understand when the conservancy tells them that the area is too small and that if you don't have a job you should go back to where you came from.' But members and non-members alike expressed frustration with the social conflicts in Uibasen. 'People live in fear in this area. I am a member and have power and benefits. But some houses are not members and are threatened by the traditional leader and by the conservancy so they get scared and pack up and leave, they even leave their jobs.' And another non-member noted, 'Political fighting happens all the time here. The people in charge just want money and they don't care about development. There is no kindergarten, no clinic.' The statements suggest that the division in the community contributes to less social cohesion.

In the case of Mayuni conservancy we find that even in the presence of ethnic heterogeneity, the community shares common social norms that bind the group and help facilitate collective action. In Mayuni conservancy common interests and shared norms were stronger in creating social cohesion or bond between conservancy members, although community members generally reported that they did not receive benefits. The findings in Uibasen conservancy shows community members although more ethnically homogeneous, did not have common interests and shared norms because the distinct groups of members versus non-members, with one group receiving benefits while the other did not. However, we find no evidence that shared social norms give rise to the development of more equitable benefit-sharing systems.

\section{Discussion}

Our study reveals that local governance institutions in both Uibasen and Mayuni conservancies have not 
developed adequate benefit-sharing systems, although benefits are a critical component in incentivizing community-based management of natural resources. In this section, we summarize the problem and consider the reasons for local governance institution not developing transparent benefit-sharing systems. We also discuss the influence of the three community characteristics (i.e., size, degree of homogeneity, and shared social norms) on the development of benefit-sharing systems. Finally we discuss the implications of our findings for local governance and benefit sharing in CBNRM.

In both conservancies we find little evidence of transparent, codified benefit-sharing systems and members do not know what they are entitled to. Rather the benefits are distributed in an uneven and ad hoc way by conservancy leaders. Although conservancies might deliver a certain benefit, it seems to only reach certain members (although not necessarily the same group). Similar trends were also observed in Tanzania (Igoe \& Croucher, 2007). In their study of wildlife conservation areas in Tanzania, Igoe and Croucher (2007) find that communities are not provided with clear regulations about benefit sharing which in some cases depend on ad hoc government directives. Conservancy management committees maybe correct in claiming to deliver certain benefits (e.g., meat), but they rarely report the percentage of members who get that benefit or the way they decide who gets the benefit (i.e., is it needs based assessment, rotation so all members get it at some point, etc.). This contributes to a situation where members develop very high expectations of what benefits they feel entitled to, and they are often disappointed with what they actually get. A transparent benefit distribution plan could improve this situation by indicating who would receive benefits and the types and amount of benefits they could expect to receive.

Local governance regulates and facilitates access to benefits as it responds to community expectations and demands (Nkhata, Breen, et al., 2012). However, local governance institutions in community based conservation continue to be fragile and sensitive to internal and external change in the community (Balint \& Mashinya, 2006; Child, 2004), and thus their capability to develop benefit-sharing systems remains limited. We find little evidence that local governance institutions have facilitated the development of benefit-sharing systems in either case. This appears common for African CBNRM in general (Igoe \& Croucher, 2007; Long, 2004; Mbaiwa, 2004; NACSO, 2008, 2010, 2011; Nkhata \& Breen, 2010; Sebele, 2010). This could be attributed to weak enforcement of the benefit-sharing policy directive and incapable (or unwilling) local governance structures. This suggests the need for more government assistance and oversight to bring about the benefit-sharing systems mandated by conservancy constitutions. Policies must set the principles for understanding and directing benefit-sharing systems towards a particular outcome that addresses community expectations. For example, in developing countries where rural communities are faced with the challenges of poverty and high unemployment, the benefit-sharing system must address these social challenges in order to enhance the conservation of natural resources. Policy guidelines would inform local governance institutions when developing the benefit-sharing systems (Nkhata, Breen, et al., 2012) rather than leaving communities without support (Igoe \& Croucher, 2007; Jones, 1999a).

Our findings support those of Balint and Mashinya (2008) who contend that benefits to participants of CBNRM programs will decline in the absence of benefit-sharing systems. Nkhata, Breen, et al. (2012) emphasized the complexity and multiple interests involved in benefit sharing. The capability of local governance institutions involves the ability to negotiate the multiple interests, expectations and values of community members (Barker, 2005; Dietz, Ostrom, \& Stern, 2003; Eade, 1997; Gruber, 2010; Meinzen-Dick \& Knox, 1999; Ostrom, 1990) to develop a benefit-sharing system with socially acceptable outcomes. We suggest that CBNRM support organizations, build capability in local governance institutions to develop benefit-sharing systems. Due to the tenuousness of the local governance institutions the support should be continuous (Balint \& Mashinya, 2006). We contend that policy guidelines would enhance the capability of local governance institutions to develop a fair and equitable benefit-sharing system, and that this would reinforce positive CBNRM outcomes. This could improve the distribution of benefits to address social challenges, improve livelihoods, and contribute to the conservation of natural resources in developing countries. We tend to thus conclude that the criticism of CBNRM for not delivering benefits (Blaikie, 2006; Buscher \& Dressler, 2007; Büscher \& Dressler, 2012; Dressler \& Büscher, 2008; Dressler et al., 2010) could be caused more by local governance institutions failure to develop benefit-sharing systems that are socially acceptable and less about the failure of CBNRM to generate the benefits.

Benefit sharing involves multiple interests with divergent expectations and experiences, which are defined by the characteristics of the community (Nkhata, Breen, et al., 2012). Thus the social interaction between members within the community and their participation (Gruber, 2010) in local governance institution is critical to develop a fair and equitable benefit-sharing systems. It is argued that heterogeneity in the community lead to more 
divergent views (Poteete \& Ostrom, 2004) which make it difficult for the local governance decision making to develop benefit-sharing systems. While Mayuni conservancy members express serious dissatisfaction with conservancy management, this did not lead to high levels of social conflict and helped insure their compliance with CBNRM policies. This confirms, earlier findings that in Mayuni the social bond between household members, households and the community is very strong (Shapi, 2003; Julie A Silva \& Mosimane, 2014). Scanlon and Kull (2009) observed that heterogeneity in Torra conservancy members did not impede benefit sharing because the common interest of conserving wildlife facilitated a more equitable distribution system. These findings suggest that heterogeneity in community based conservation (Poteete \& Ostrom, 2004) do not impede benefit sharing, and sustainable local governance of natural resources, although it complicates the development of fair benefit-sharing system. But, social capital within a community has the potential to facilitate equitable benefit sharing (Nkhata, Breen, et al., 2012; Nkhata, Breen, \& Abacar, 2009; Scanlon \& Kull, 2009) if transparent benefit-sharing systems exist.

In contrast, a homogeneous community is more likely to work together (Meinzen-Dick \& Knox, 1999; Thompson, Sultana, \& Islam, 2003). Homogeneity is important in the use and management of natural resources (Nkhata, Breen, et al., 2012; Ostrom, 1990) and thus could facilitate decision making on benefit-sharing systems. However, the more ethnically homogeneous community (Uibasen) in our analysis actually expressed more dissatisfaction with conservancy management benefits distribution, based on their perceptions of what is fair and just. We find that elite capture and alignment with traditional authority structures play a stronger role in shaping the perception of equitable benefits than local governance institutions. Although homogeneity could facilitate decision making to develop benefit-sharing systems, we note that other social factors such as elite capture and weak social capital could impede the development of benefit-sharing systems that facilitates the distribution of benefits to community members.

Both conservancies have made changes to their constitutions to address governance issues related to the conservancy management structure and decision-making processes as the conservancy evolved. This suggests that local characteristics are not the driving force in developing benefit-sharing systems. Rather it points to the need for a more active role of the government and the NGOs in assisting local governance institutions in developing and implementing the plans. Centralized enforcement is likely to play an important role in ensuring that these systems lead to equitable distribution of benefits. The absence of benefit-sharing systems in both cases made it difficult for the community to understand the type and amounts of benefits that they could receive. This contributed to the increased perception within the community that the current benefit-sharing systems in both cases are unfair. Local governance institutions that share benefits are expected to do so in a fair and equitable manner (Gruber, 2010; Jones, 1999c; MET, 1995; Mulonga \& Murphy, 2003). Fairness involves the ability of the local governance institution to consider the views, perceptions and expectation of community members when making decisions about benefits (Gruber, 2010; Lockwood, Davidson, Curtis, Stratford, \& Griffith, 2010). Community participation has the potential to assist fairness because it allows for diverse views, interest and values of members to be considered when the benefit-sharing systems are developed (Lockwood et al., 2010; Sebele, 2010). We propose that fairness and equitable sharing of benefits can only be achieved when transparent policies are implemented, and enforced, to fulfill the objective of the benefit-sharing systems.

\section{Conclusion}

The relationship between local governance and benefit sharing has large implications for the success or failure of CBNRM programs. Benefits are critical if CBNRM programs are to address the social and economic needs of community members (Gruber, 2010; Leach, Mearns, \& Scoones, 1999; Meinzen-Dick \& Knox, 1999). Conservancies studied in this analysis lack the types of benefit-sharing systems mandated by Namibian legislation which CBNRM deem critical for equitable CBNRM outcomes. We therefore make the following conclusions:

- We find evidence that local governance institutions do not develop and implement clear plans for the equitable distribution of benefits, although other local-level policies regarding CBNRM do evolve over time.

- Our findings indicate that local governance institutions have limited capacity to develop benefit-sharing schemes and that the national government fails to monitor and enforce policy requirements at community level. Consequently, national policies are needed to facilitate and enforce benefit-sharing systems in conservancies. 
- We suggest that government and CBNRM support organizations develop examples of benefit-sharing policies and capacitate local governance institutions to develop and implement benefit-sharing systems, informed by community expectations and experiences.

- Our study strongly suggests that the development of socially acceptable benefit-sharing systems requires more attention if CBNRM is to maintain support within communities.

In addition, our study finds little evidence the three community characteristics (i.e., size of community, level of community homogeneity, and existence of shared norms) highlighted in the literature as facilitating decision making in CBNRM actually contribute to better local governance for benefit sharing. But these characteristics do alter the perceptions of community members and shape their willingness to participate in these programs. We find small spatial units do not necessarily lead to more equitable benefit sharing or facilitate better local governance regarding benefits distribution. The local governance institutions appear constrained not by distance, but by the number of members that are eligible for benefits. In the absence of high conservancy revenues, members are more likely to feel that they do not receive a fair share. The difficulties associated with developing equitable benefit-sharing systems in high-density areas may reduce incentives for local governments to implement these measures. In such high density conservancies we suggests a benefit-sharing system that prioritizes community wide benefits with focused outcomes defined through on-going dialogue with community members in order to address their expectations and experiences.

\section{Acknowledgements}

We would like to thank the community members of Uibasen and Mayuni conservancies for their participation in the studies. We also appreciate the UNAM research students who helped to collect and translate the data. We express gratitude to members of the INSAKA community for comments on the article. This material is based upon work supported by the National Science Foundation under Grant Number BCS 1042888. Any opinions, findings, conclusions or recommendations expressed in this material are those of the authors and do not necessarily reflect the views of the National Science Foundation. The authors accept all responsibility for any errors.

\section{References}

Adams, F., Werner, W., \& Vale, P. C. J. (1990). The land issue in Namibia: An inquiry (Vol. 1). Namibia Institute for Social and Economic Research.

Agrawal, A. (2001). Common property institutions and sustainable governance of resources. World development, 29(10), 1649-1672. http://dx.doi.org/10.1016/S0305-750X(01)00063-8

Agrawal, A., \& Gibson, C. C. (1999). Enchantment and disenchantment: the role of community in natural $\begin{array}{llll}\text { resource } & \text { conservation. }\end{array}$ http://dx.doi.org/10.1016/S0305-750X(98)00161-2

Ashley, C., \& LaFranchi, C. (1997). Livelihood strategies of rural households in Caprivi: implications for conservancies and natural resource management: Directorate of Environmental Affairs, Ministry of Environment and Tourism Windhoek, Namibia.

Balint, P. J., \& Mashinya, J. (2006). The decline of a model community-based conservation project: Governance, capacity, and devolution in Mahenye, Zimbabwe. Geoforum, 37(5), 805-815. http://dx.doi.org/10.1016/j.geoforum.2005.01.011

Balint, P. J., \& Mashinya, J. (2008a). Campfire during Zimbabwe's national crisis: Local impacts and broader implications for community-based wildlife management. Society and Natural Resources, 21(9), 783-796. http://dx.doi.org/10.1080/08941920701681961

Balint, P. J., \& Mashinya, J. (2008b). CAMPFIRE through the lens of the 'commons' literature: Nyaminyami Rural District in post-2000 Zimbabwe. Journal of Southern African Studies, 34(1), 127-143. http://dx.doi.org/10.1080/03057070701832924

Barker, A. (2005). Capacity building for sustainability: Towards community development in coastal Scotland. Journal of Environmental Management, 75(1), 11-19. http://dx.doi.org/10.1016/j.jenvman.2004.11.002

Blaikie, P. (2006). Is small really beautiful? Community-based natural resource management in Malawi and Botswana. World development, 34(11), 1942-1957. http://dx.doi.org/10.1016/j.worlddev.2005.11.023

Buscher, B., \& Dressler, W. (2007). Linking neoprotectionism and environmental governance: On the rapidly increasing tensions between actors in the environment-development nexus. Conservation and Society, 5(4), 
586.

Büscher, B., \& Dressler, W. (2012). Commodity conservation: The restructuring of community conservation in South Africa and the Philippines. Geoforum, 43(3), 367-376. $\mathrm{http}: / / \mathrm{dx}$.doi.org/10.1016/j.geoforum.2010.06.010

Chambers, R. (1983). Rural Development: putting the last first. Routledge.

Child, B. (2004). Parks in Transition:"Biodiversity, Rural Development and the Bottom Line". London: Earthscan.

Dietz, T., Ostrom, E., \& Stern, P. C. (2003). The struggle to govern the commons. science, 302(5652), 1907-1912.

Dressler, W., \& Büscher, B. (2008). Market triumphalism and the CBNRM 'crises' at the South African section of the Great Limpopo Transfrontier Park. Geoforum, 39(1), 452-465. $\mathrm{http}: / / \mathrm{dx}$.doi.org/10.1016/j.geoforum.2007.09.005

Dressler, W., Buscher, B., Schoon, M., Brockington, D., Hayes, T., Kull, C. A., . . Shrestha, K. (2010). From hope to crisis and back again? A critical history of the global CBNRM narrative. Environmental Conservation, 37(1), 5-15. http://dx.doi.org/10.1017/S0376892910000044

Eade, D. (1997). Capacity-building: an approach to people-centred development. Oxfam. http://dx.doi.org/10.3362/9780855986735

Fabricius, C., Koch, E., Magome, H., \& Turner, S. (2004). Rights, resources and rural development. London: Earthscan.

Gruber, J. S. (2010). Key principles of community-based natural resource management: A synthesis and interpretation of identified effective approaches for managing the commons. Environmental management, 45(1), 52-66. http://dx.doi.org/10.1007/s00267-008-9235-y

Hoole, A. (2009a). Community-based conservation and protected areas in Namibia: Social-ecological linkages for biodiversity. UNIVERSITY OF MANITOBA.

Hoole, A. (2009b). Place-power-prognosis: Community-based conservation, partnerships, and ecotourism enterprises in Namibia. International Journal of the Commons, 4(1), 78-99.

Hulme, D., \& Murphree, M. (2001). African wildlife and livelihoods: the promise and performance of community conservation: James Currey Ltd.

Humphrey, A., \& Humphrey, E. (2003). A profile of four communal area conservancies in Namibia. DFID: London, UK. Ministry of Environment and Tourism. Windhoek, Namibia.

Igoe, J., \& Croucher, B. (2007). Conservation, commerce, and communities: the story of community-based wildlife management areas in Tanzania's northern tourist circuit. Conservation and Society, 5(4), 534.

Jacobsohn, M., \& Owen-Smith, G. (2003). Integrating conservation and development: A namibian case study. Nomadic Peoples, 7(1), 92-109. http://dx.doi.org/10.3167/082279403782088831

Jones, B. T. B. (1999a). Community management of natural resources in Namibia. Paper presented at the Scandinavian Seminar College's Africa Project, SCC Africa Project.

Jones, B. T. B. (1999b). Policy lessons from the evolution of a community - based approach to wildlife management, Kunene Region, Namibia. Journal of International Development, 11(2), 295-304. http://dx.doi.org/10.1002/(SICI)1099-1328(199903/04)11:2<295::AID-JID583>3.0.CO;2-U

Jones, B. T. B. (1999c). Rights, revenue and resources: the problems and potential of conservacies as community wildlife management institutions in Namibia. IIED Biodeversity Group.

Jones, B. T. B., \& Murphree, M. W. (2004). Community-based natural resource management as a conservation mechanism: Lessons and directions. In Parks in Transition: Biodiversity, Rural Development, and the Bottom Line (pp. 63-103). London: Earthscan.

Leach, M., Mearns, R., \& Scoones, I. (1999). Environmental entitlements: Dynamics and institutions in community-based natural resource management. World development, 27(2), 225-247. http://dx.doi.org/10.1016/S0305-750X(98)00141-7

Lockwood, M., Davidson, J., Curtis, A., Stratford, E., \& Griffith, R. (2010). Governance principles for natural resource management. Society and Natural Resources, 23(10), 986-1001. 
http://dx.doi.org/10.1080/08941920802178214

Long, S. A. (2004). Livelihoods and CBNRM in Namibia: the findings of the WILD Project: final technical report of the Wildlife Integration for Livelihood Diversification Project (WILD). Wildlife Integration for Livelihood Diversification Project.

Mbaiwa, J. E. (2004). The socio-economic benefits and challenges of a community-based safari hunting tourism in the Okavango Delta. Botswana. Journal of Tourism Studies, 15(2), 37-50.

Meinzen-Dick, R., \& Knox, A. (1999). Collective action, property rights, and devolution of natural resource management: A conceptual framework. Paper presented at the Workshop on Collective Action, Property Rights, and Devolution of Natural Resource, Puerto Azul, Philippines, June.

MET. (1995). Wildlife management, utilisation, and tourism in communal areas: policy document: Ministry of Environment and Tourism, Namibia, Windhoek.

Mosimane, A. W. (1999). Livelihood, governance and organisation in Mayuni Conservancy: University of Namibia, Multi-Disciplinary Research Centre, Social Sciences Division.

Mulonga, S., \& Murphy, C. A. (2003). Spending the money: The experience of conservancy benefit distribution in Namibia up to mid-2003. Directorate of Environmental Affairs, Ministry of Environment and Tourism. Discussion Paper,63. Windhoek, Namibia.

Murphree, M. W. (1993). Communities as resource management institutions: Sustainable Agriculture Programme, International Institute for Environment and Development London.

Murphree, M. W. (1995). Optimal principles and pragmatic strategies: creating an enabling politico-legal environment for community based natural resource management (CBNRM). The commons without the tragedy, 3-6.

NACSO. (2006). Namibia communal conservancies: a review of progress and challenges in 2005 NACSO. Windhoek, Namibia.

NACSO. (2008). Namibia communal conservancies: a review of progress and challenges in 2007 NACSO. Windhoek, Namibia.

NACSO. (2010). Namibia communal conservancies: a review of progress and challenges in 2009. NACSO. Windhoek, Namibia.

NACSO. (2011). Namibia communal conservancies: a review of progress and challenges in 2010. NACSO. Windhoek, Namibia.

Nkhata, B. A., Breen, C., \& Mosimane, A. (2012). Engaging common property theory: implications for benefit sharing research in developing countries. International Journal of the Commons, 6(1), 52-69.

Nkhata, B. A., \& Breen, C. M. (2010). Performance of community-based natural resource governance for the Kafue Flats (Zambia). Environmental Conservation, 37(03), 296-302. http://dx.doi.org/10.1017/S0376892910000585

Nkhata, B. A., Breen, C. M., \& Abacar, A. (2009). Social capital, community-based governance and resilience in an African artisanal river fishery. Water SA, 35(1), 45-53.

Nkhata, B. A., Mosimane, A., Downsborough, L., Breen, C., \& Roux, D. J. (2012). A Typology of Benefit Sharing Arrangements for the Governance of Social-Ecological Systems in Developing Countries. Ecology and Society, 17(1), 17. http://dx.doi.org/10.5751/ES-04662-170117

Nott, C., \& Jacobsohn, M. (2004). Key issues in Namibia's communal conservancy movement. In Rights, Resources and Rural Development: Community-based Natural Resource Management in Southern Africa, eds. C. Fabricius, E. Koch, H. Magome and S. Turner (pp. 194-199). London: Earthscan.

Ostrom, E. (1990). Governing the commons: The evolution of institutions for collective action. Cambridge University Press. http://dx.doi.org/10.1017/CBO9780511807763

Poteete, A. R., \& Ostrom, E. (2004). Heterogeneity, group size and collective action: The role of institutions in forest management. Development and change, 35(3), 435-461. http://dx.doi.org/10.1111/j.1467-7660.2004.00360.x

Scanlon, L. J., \& Kull, C. A. (2009). Untangling the links between wildlife benefits and community-based conservation at Torra Conservancy, Namibia. Development Southern Africa, 26(1), 75-93. http://dx.doi.org/10.1080/03768350802640107 
Sebele, L. S. (2010). Community-based tourism ventures, benefits and challenges: Khama rhino sanctuary trust, Central District, Botswana. Tourism Management, 31(1), 136-146. http://dx.doi.org/10.1016/j.tourman.2009.01.005

Shapi, M. (2003). Mayuni Conservancy socio-economic and livelihood approaches, with respect to contemporary natural resource conservation. Community Based Natural Resources Management Programme, Multidisciplinary rsearch Centre, Windhoek. Namibia.

Silva, J. A., \& Mosimane, A. (2014). "How Could I Live Here and Not Be a Member?": Economic Versus Social Drivers of Participation in Namibian Conservation Programs. Human Ecology, 42(2), 183-197. http://dx.doi.org/10.1007/s10745-014-9645-9

Silva, J. A., \& Mosimane, A. W. (2012). Conservation-Based Rural Development in Namibia: A Mixed-Methods Assessment of Economic Benefits. The Journal of Environment \& Development. http://dx.doi.org/10.1177/1070496512469193

Suich, H., \& Child, B. (2009). Evolution and innovation in wildlife conservation: parks and game ranches to transfrontier conservation areas. Earthscan/James \& James.

Thakadu, O. (2005). Success factors in community based natural resources management in northern Botswana: Lessons from practice. Paper presented at the Natural resources forum. http://dx.doi.org/10.1111/j.1477-8947.2005.00130.x

Thompson, P. M., Sultana, P., \& Islam, N. (2003). Lessons from community based management of floodplain fisheries in Bangladesh. Journal of Environmental Management, 69(3), 307-321. http://dx.doi.org/10.1016/j.jenvman.2003.09.014

Uiseb, K., \& Mosimane, A. W. (2004). Livelihood and tourism enterprises in Uibasen Conservancy: University of Namibia, Multidisciplinary Research and Consultancy Centre, Life Science Division.

\section{Copyrights}

Copyright for this article is retained by the author(s), with first publication rights granted to the journal.

This is an open-access article distributed under the terms and conditions of the Creative Commons Attribution license (http://creativecommons.org/licenses/by/3.0/). 